\title{
POSITIVE SOLUTIONS FOR BOUNDARY VALUE PROBLEMS
} INVOLVING NONLINEAR FRACTIONAL $q$-DIFFERENCE EQUATIONS

\author{
WENGUI YANG
}

Abstract. In this work, we investigate the eigenvalue intervals of nonlinear boundary value problems involving fractional $q$-difference equations by means of the properties of the Green function and Guo-Krasnosel'skii fixed point theorem on cones. Furthermore, some sufficient conditions for the nonexistence and existence of at least one or two positive solutions for the boundary value problem are established. As applications, some examples are presented to illustrate the main results.

Mathematics subject classification (2010): 34K20, 92B20.

Keywords and phrases: fractional $q$-difference, boundary value problems, positive solutions, fixed point theorem, eigenvalue.

\section{REFERENCES}

[1] R.P. Agarwal, Certain fractional $q$-integrals and $q$-derivatives, Proc. Cambridge Philos. Soc., 66 (1969), 365-370.

[2] R.P. AgARWAL, B. AHMAD, Existence theory for anti-periodic boundary value problems of fractional differential equations and inclusions, Comput. Math. Appl., 62 (2011), 1200-1214.

[3] R.P. Agarwal, V. Lakshmikantham, J.J. Nieto, On the concept of solution for fractional differential equations with uncertainty, Nonlinear Anal., 72 (2010), 2859-2862.

[4] R.P. Agarwal, D. O’Regan, S. StanĚK, Positive solutions for Dirichlet problems of singular nonlinear fractional differential equations, J. Math. Anal. Appl., 371 (2010), 57-68.

[5] B. Ahmad, J.J. Nieto, J. Pimentel, Some boundary value problems of fractional differential equations and inclusions, Comput. Math. Appl., 62 (2011), 1238-1250.

[6] W.A. Al-Salam, Some fractional q-integrals and q-derivatives, Proc. Edinb. Math. Soc., 15, 2 (1966-1967), 135-140.

[7] F.M. Atici, P.W. Eloe, Fractional q-calculus on a time scale, J. Nonlinear Math. Phys., 14 (2007), 333-344.

[8] M. EL-Shahed, F.M. AL-AsKAR, Positive solutions for boundary value problem of nonlinear fractional $q$-difference equation, ISRN Math. Anal., 2011 (2011), Art. ID 385459, 12 pages.

[9] M. EL-Shahed, M. AL-YAMI, On the existence and uniqueness of solutions for $q$-fractional boundary value problem, Int. J. Math. Anal., 5 (2011), 1619-1630.

[10] M. El-Shahed, H.A. Hass An, Positive solutions of $q$-difference equation, Proc. Amer. Math. Soc., 138 (2010), 1733-1738.

[11] R.A.C. FERREIRA, Nontrivial solutions for fractional q-difference boundary value problems, Electron. J. Qual. Theory Differ. Equ., 70 (2010), 1-10.

[12] R.A.C. FERREIRA, Positive solutions for a class of boundary value problems with fractional $q$ differences, Comput. Math. Appl., 61 (2011), 367-373.

[13] D.J. Guo, V. LAKshmikantham, Nonlinear problems in abstract cones, Academic Press, Boston, MA, 1988.

[14] F.H. JACKSON, On q-functions and a certain difference operator, Trans. Roy. Soc. Edinburgh, 46 (1908), 253-281.

[15] F.H. JACKSON, On q-definite integrals, Quart. J. Pure Appl. Math., 41 (1910), 193-203.

[16] V. KaC And P. Cheung, Quantum Calculus, Springer, New York, NY, USA, 2002. 
[17] M.A. KRasnosel's 'sir, Positive solutions of operator equations, Noordhoff, Groningen, The Netherlands, 1964.

[18] C. LI, X. Luo, Y. ZHou, Existence of positive solutions of the boundary value problem for nonlinear fractional differential equations, Comput. Math. Appl., 59 (2010), 1363-1375.

[19] S. LiANG, J. ZHANG, Existence and uniqueness of positive solutions for three-point boundary value problem with fractional q-differences, J. Appl. Math Comput., 40 (2012), 277-288.

[20] J. MA, J. YANG, Existence of solutions for multi-point boundary value problem of fractional qdifference equation, Electron. J. Qual. Theory Differ. Equ., 92 (2011), 1-10.

[21] G. WANG, L. ZhANG, S.K. NTOUYAS, Existence of multiple positive solutions of a nonlinear arbitrary order boundary value problem with advanced arguments, Electron. J. Qual. Theory Differ. Equ., 15 (2012), 1-13.

[22] P.M. RAJKović, S.D. Marinković, AND M.S. StAnković, On q-analogues of caputo derivative and Mittag-Leffler function, Fract. Calc. Appl. Anal., 10 (2007), 359-373.

[23] P.M. RAJKović, S.D. Marinković, AND M.S. StAnković, Fractional integrals and derivatives in q-calculus, Appl. Anal. Discrete Math., 1 (2007), 311-323.

[24] X. YANG, Z. WEI, W. DONG, Existence of positive solutions for the boundary value problem of nonlinear fractional differential equations, Commun. Nonlinear Sci. Numer. Simul., 17 (2012), 8592.

[25] C. Yuan, D. Jiang, D. O'Regan, R.P. Agarwal, Multiple positive solutions to systems of nonlinear semipositone fractional differential equations with coupled boundary conditions, Electron. J. Qual. Theory Differ. Equ., 13 (2012), 1-17.

[26] Y. ZHAO ET AL., Positive solutions to boundary value problems of nonlinear fractional differential equations, Abstr. Appl. Anal., 2011 (2011), Art. ID 390543, 16 pages. 